\title{
Correction to: Medical Treatment Options for Patients with Epidermal Growth Factor Receptor Mutation-Positive Non-Small Cell Lung Cancer Suffering from Brain Metastases and/or Leptomeningeal Disease
}

\author{
Maximilian Hochmair ${ }^{1}$
}

Published online: 2 October 2018

(C) The Author(s) 2018

Correction to: Targeted Oncology (2018) 13:269-285

https://doi.org/10.1007/s11523-018-0566-1

Enhanced digital features were retrospectively added to this article.

To view enhanced digital features for this article go to https:// doi.org/10.6084/m9.figshare. 7094075 .

Open Access This article is distributed under the terms of the Creative Commons Attribution-NonCommercial 4.0 International License (http://creativecommons.org/licenses/bync/4.0/), which permits any noncommercial use, distribution, and reproduction in any medium, provided you give appropriate credit to the original author(s) and the source, provide a link to the Creative Commons license, and indicate if changes were made.

The online version of the original article can be found at https://oi.org/ 10.1007/s11523-018-0566-1

Maximilian Hochmair

maximilian.hochmair@wienkav.at

1 Department of Respiratory and Critical Care Medicine and Ludwig Boltzmann Institute for COPD and Respiratory Epidemiology,

Vienna, Austria 